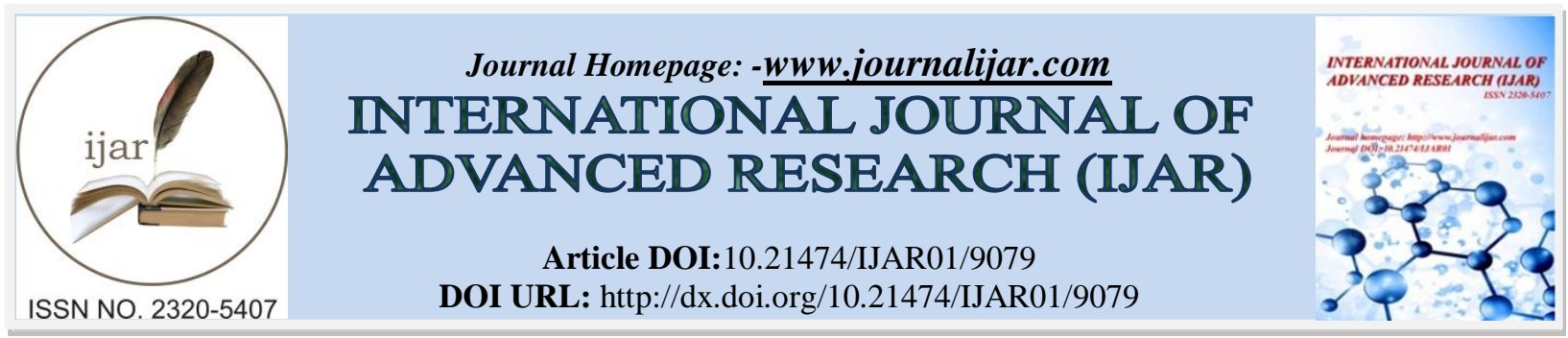

RESEARCH ARTICLE

\title{
PROPERTIES OF STONE WOOL PRIMARY FIBER LAYERS PRODUCEDWITH DIFFERENT CONTENTS OD BLAST FURNACE SLAG.
}

\author{
Raif Seferović ${ }^{1}$, Aida Imamović ${ }^{2}$, Derviš Mujagić ${ }^{1}$, Marina Jovanović ${ }^{2}$, Amel Zahirović ${ }^{1}$ And Dejana \\ Kasapović². \\ 1. University of Zenica, Institute "Kemal Kapetanovic", Zenica, BiH. \\ 2. University of Zenica, Faculty of Metallurgy and Technology, Zenica, BiH.
}

\section{Manuscript Info}

\section{Manuscript History}

Received: 15 March 2019

Final Accepted: 17 April 2019

Published: May 2019

Key words:-

stone wool, mineral fiber, blast furnace

slag, spinning machine,nanoindentation.

\begin{abstract}
Among the inevitable by-products of the metallurgical industry, special importance is given to waste from the iron and steel production. The blast furnace slag is not only the by-product, but rather it is also of a valuable resource as a substitute for the natural mineral aggregates. The chemical composition of blast furnace slag is similar to the composition of natural mineral rocks and is recognized as a potential raw material in stone wool production. The primary layer formation process is an important part of the mineral wool production line and it was simulated experimentally on a model of the spinning machine.

This paper presents research of the mineral fibers mechanical properties based on mixture of blast furnace slag and diabase. Based on the results of a study carried out on the formation and the properties of stone wool fibers, it can be concluded that the blast furnace slag as a dominant component can be used to produce stone wool.
\end{abstract}

Copy Right, IJAR, 2019,. All rights reserved.

\section{Introduction:-}

Stone wool is a non-metallic, inorganic product manufactured from a carefully controlled mix of raw materials, mainly comprising either stone or silica which are heated to a high temperature until molten. Production techniques are based on spinning the molten mineral melt which goes to the fiberizing area. Fiberizing combines a mechanical centrifugal drawing of the molten melt through a rotating device drilled with holes, or through rotating cylinders, and a fibre attenuation by means of high temperature gas jet streams or compressed air, figure 1 [1].

Corresponding Author:- Raif Seferović.

Address:-University of Zenica, Institute "Kemal Kapetanovic", Zenica, BiH. 


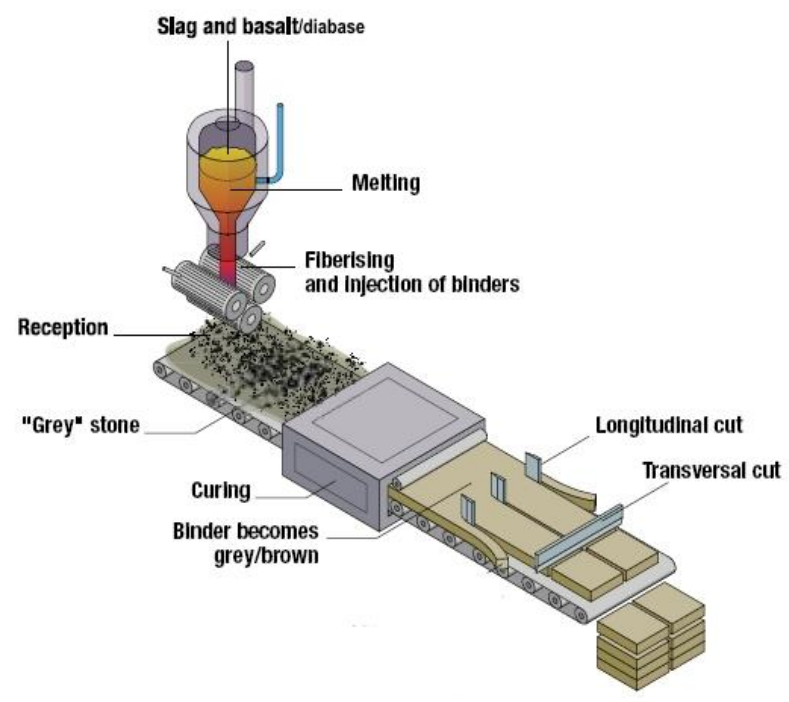

Figure 1:-Manufacturing mineral stone wool [1].

Stone wool production process is highly complex consisting of several different production phases. Production phases which most significantly affect the mineral wool quality are the melt fiberization on the spinning machine and primary layer formation in the collecting chamber [2].

Stone wool is made from volcanic rock and an increasing share of recycled material like as blast furnace slag. The chemical composition of blast furnace slag is similar to the composition of natural mineral rocks and is recognized as a potential raw material in mineral wool production [3]. Mineral slag wool is a product made from blast furnace slag.Using blast furnace slag in stone wool production reduces the consumption of natural minerals.

Mass production in the integral steel work, which implies steady operation of the blast furnace, and therefore the high production of blast furnace slag are a safe raw material for the production of stone wool.

The present paper investigated the process of the stone wool fabrication using blast furnace slag modified by natural raw materials on the way to recognise the potential for the use of blast furnace slag from ArcelorMittal Zenica steel factory, which can be used in the technology of stone wool production with the modification of a raw mixture with natural mineral aggregates [4].

\section{Experimental parts}

\section{1. Materials}

Mineral fiber samples were produced on the basis of a blast furnace slag and of diabase, which was used as an additive to modify the chemical composition of molten melt.

The blast furnace slag used in this experiment was collected from ArcelorMittal Zenica. Average chemical composition of potential raw materials for fiber primary layer production is given in the table 1 [3].

Table 1:-Chemical composition of raw materials for fiber samples.

\begin{tabular}{|l|l|l|l|l|l|}
\hline \multirow{2}{*}{ Raw material } & \multicolumn{5}{|c|}{ Chemical composition (\%) } \\
\cline { 2 - 6 } & $\mathrm{SiO}_{2}$ & $\mathrm{CaO}$ & $\mathrm{Al}_{2} \mathrm{O}_{3}$ & $\mathrm{MgO}$ & $\mathrm{Fe}_{2} \mathrm{O}_{3}$ \\
\hline Blast furnace slag & 38.12 & 42.3 & 8.88 & 5.48 & 0.29 \\
\hline Diabase & 43.76 & 12.26 & 22.83 & 4.36 & 10.24 \\
\hline
\end{tabular}

Mineral fiber samples were produced on the basis up 30 to $60 \%$ of a blast furnace slag and rest was diabase. 


\subsection{Mineral fiber formation process}

Laboratory spinning machine used for the fiberization simulationof primary layer formation. The process of fiberisation includes the transformation of the melt in to the solid structure of fibre form. The mixtures of blast furnace slag and diabase were melted in an induction furnace and homogenized at a temperature of $1450^{\circ} \mathrm{C}$. The mineral molten melt first enters the melt reservoir and is then supplied to the spinning machine with a hollow perforated rotor and a vertical collecting chamber, figure 2 [5].

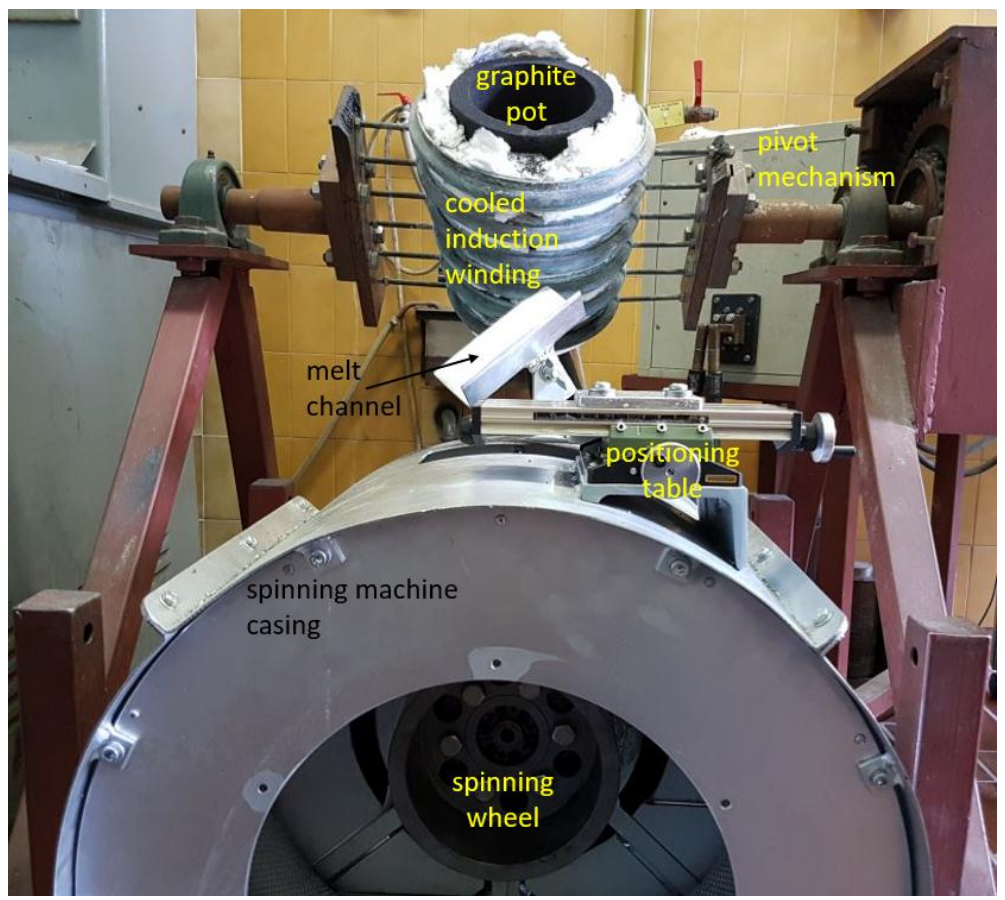

Figure 2:-Laboratory spinning machine used for fiberization [5].

A good quality primary layer is characterized by a homogeneous structure of the fiber deposit [6].

\section{Characterization of mineral fiber}

\subsection{CHEMICAL ANALYSIS OF PRIMARY FIBER LAYER}

Solid fibers trapped inside the spinner casing were collected for chemical analysis. Chemical composition of samples was determined by the XRF method on a powdered sample. Due to a high silicon ( $\mathrm{Si}$ ) content. a reference measurement on a standard $\mathrm{SiO}_{2}$ sample was made simultaneously to determine the correct ratio of other components. Chemical composition of molten samples is given in the table 2 [4].

Table 2:-Chemical composition of molten samples [4].

\begin{tabular}{|c|c|c|c|c|c|c|c|c|}
\hline \multirow[t]{2}{*}{ Sample } & \multirow{2}{*}{$\begin{array}{l}\text { Content of } \text { blast } \\
\text { furnace slag, \% }\end{array}$} & \multicolumn{7}{|c|}{ Chemical composition. (\%) } \\
\hline & & $\mathrm{SiO}_{2}$ & $\mathrm{Al}_{2} \mathrm{O}_{3}$ & $\mathrm{Fe}_{2} \mathrm{O}_{3}$ & $\mathrm{MgO}$ & $\mathrm{CaO}$ & $\mathrm{MnO}$ & $\mathrm{TiO}_{2}$ \\
\hline B3D7 & 30 & 49.00 & 13.00 & 6.60 & 10.36 & 15.95 & 0.95 & 0.87 \\
\hline B4D6 & 40 & 47.48 & 12.29 & 5.60 & 10.20 & 18.52 & 1.26 & 0.82 \\
\hline B5D5 & 50 & 46.01 & 11.59 & 3.86 & 9.93 & 22.70 & 1.72 & 0.66 \\
\hline B6D4 & 60 & 46.92 & 12.21 & 4.73 & 9.91 & 20.71 & 1.50 & 0.72 \\
\hline
\end{tabular}

Figure 3 shows macro images of fibers produced from molten mixtures B3D7-B6D4 combined with microscope images of fibers inserted in metallographic samples. The average cross-sectionaldiameter of the fiber is about 11 microns. 

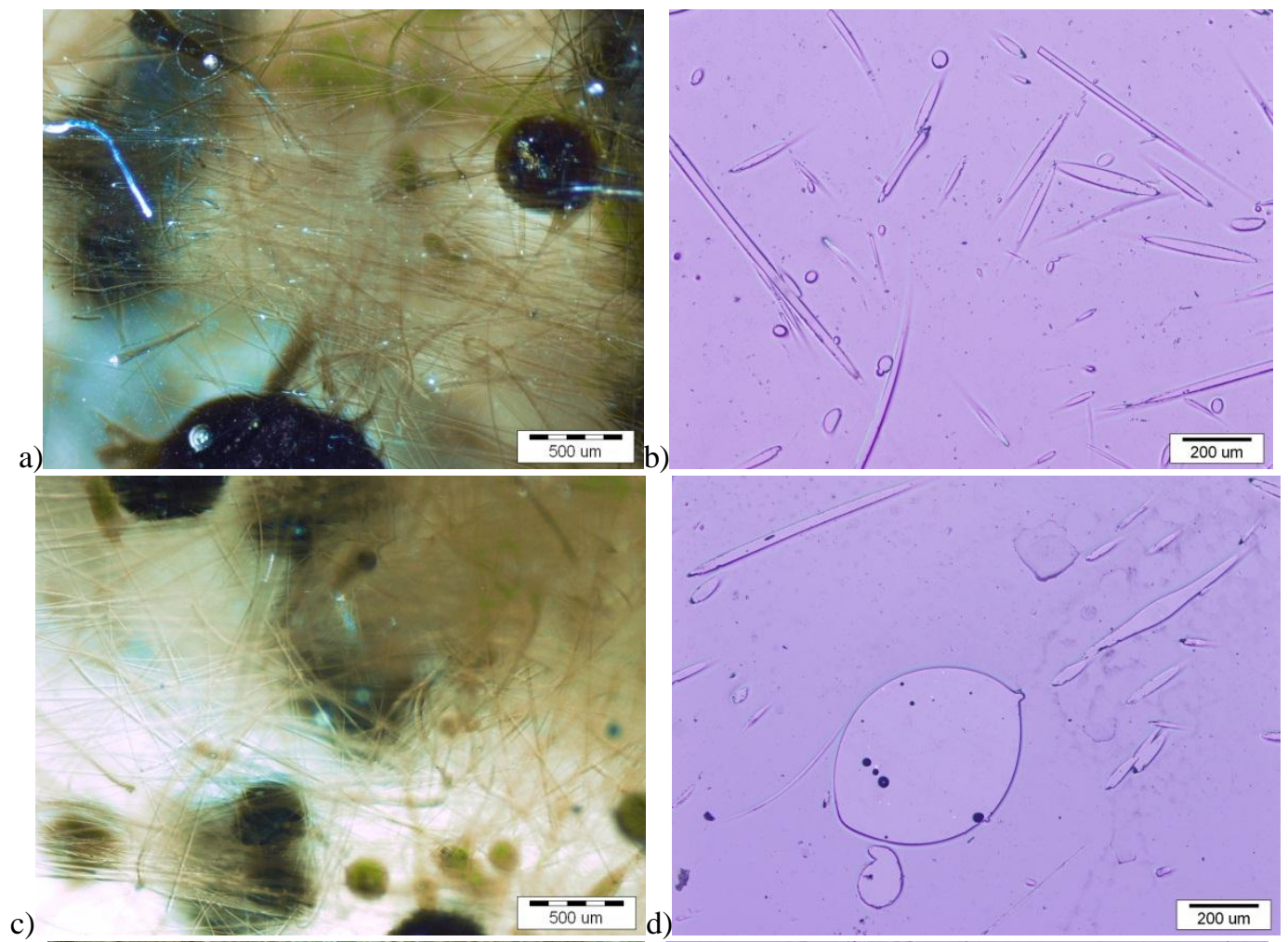

c)
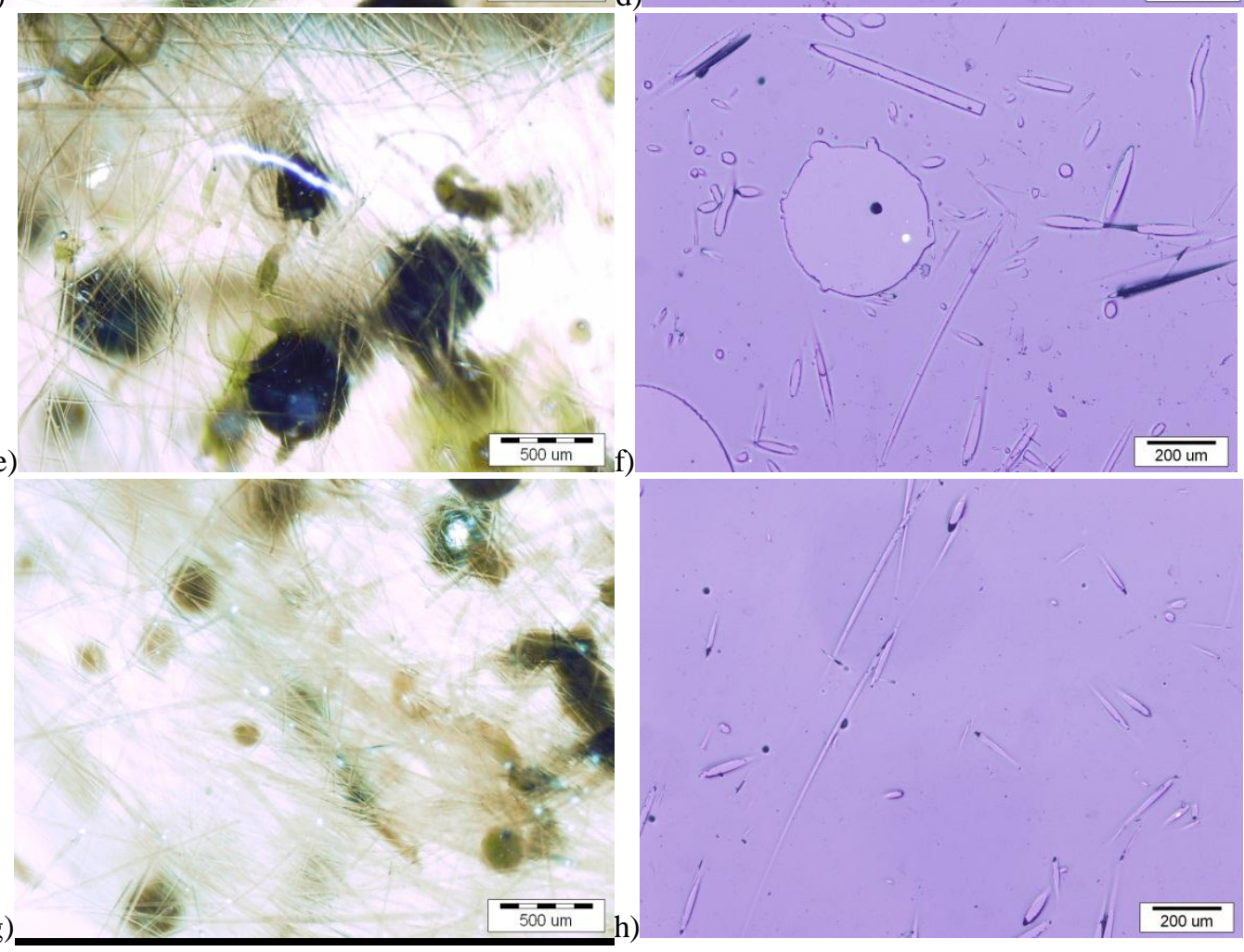

Figure 3:-Macro in micro image of produced fibers; a-b) B3D7. c-d) B4D6 e-f) B5D5 g-h) B6D4.

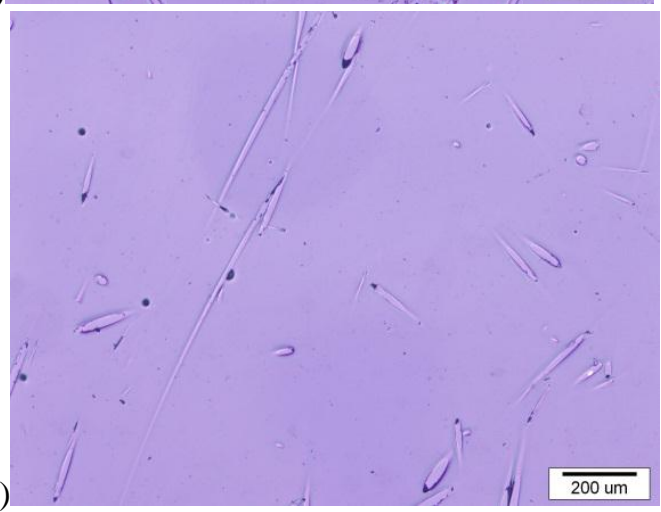

From the presented images on the micro and macro level on figure 3 and the corresponding analysis of the average diameter of the fibers in the samples it can be concluded. the structure of the fibers is comparable with the sample structures obtained on previous analysis cases with other materials from the area of stone wool production processes [4]. 


\subsection{Differential Scanning Calorimetry Analysis}

The differential scanning calorimetry (DSC) curves and latent heat of fusion were measured by a device STA 449C Jupiter. Experiments were conducted with a heating rate of $10 \mathrm{~K} / \mathrm{min}$. in Ar protective atmosphere and with samples in graphite crucibles. Heating was continued until $1550{ }^{\circ} \mathrm{C}$ and was followed by cooling down to room temperature. Results will first be presented in common graphs for heating, figure 4, with marked characteristic temperatures.

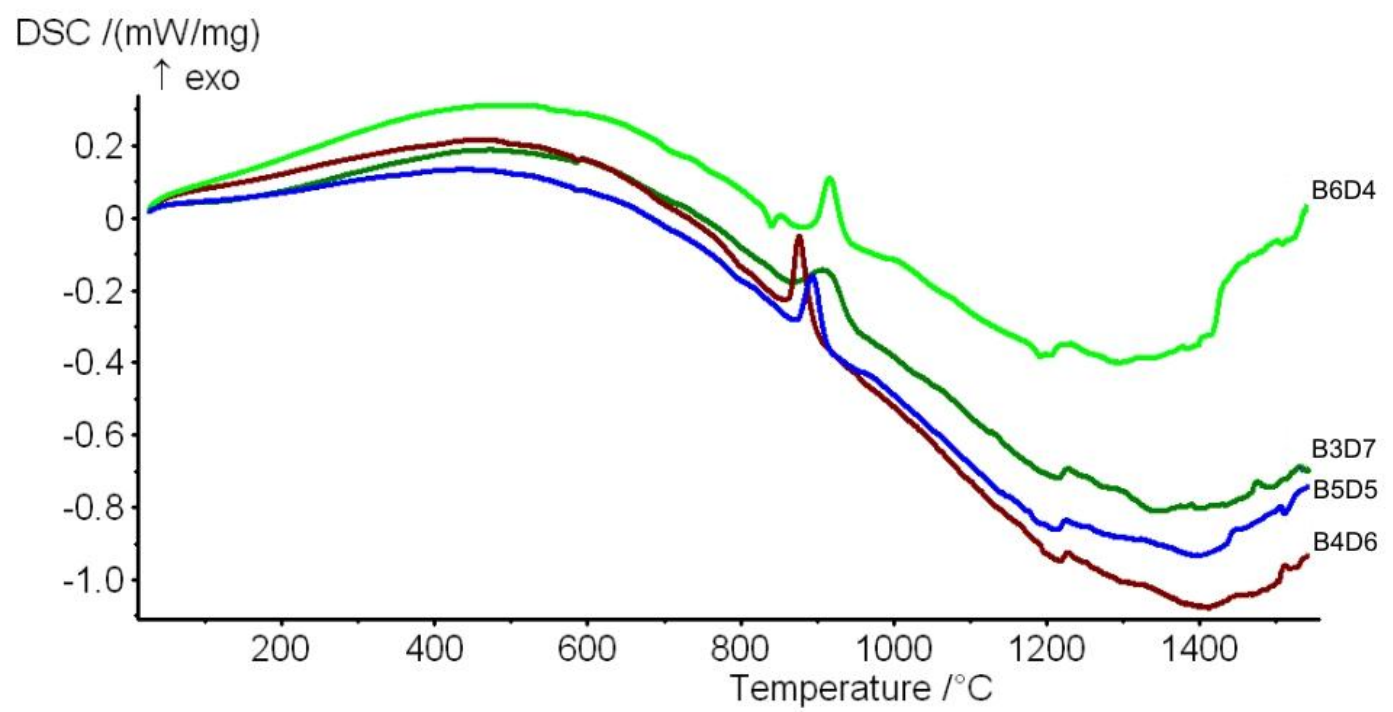

Figure 4:-DSC heating curves of fiber samples B3D7 - B6D4 [4].

Melting of samples takes place in different temperature regions depending on their chemical composition presented in table 2. The curves are relatively similar with a slight deviation of sample B6D4. All samples exhibit the first peak in the temperature region of $860{ }^{\circ} \mathrm{C}$ to $890{ }^{\circ} \mathrm{C}$ which represents a crystallographic transformation.

\subsection{Nanoindentation Results Of Primary Fiber Layer}

Mechanical tests were performed on a Nanoindenter AG 200 using DCMII measuring head which allowed greater sensitivity under small loads. The measurement result was Young's modulus and sample hardness as a function of imprint depth. Imprints on fibers based on B4D6 and B6D4 mixtures shows figure 5, [4, 7].

Considering the fact that hardness and Young's modulus values decrease with imprint depth reference values were averages between the depth of $100 \mathrm{~nm}$ and $200 \mathrm{~nm}$.
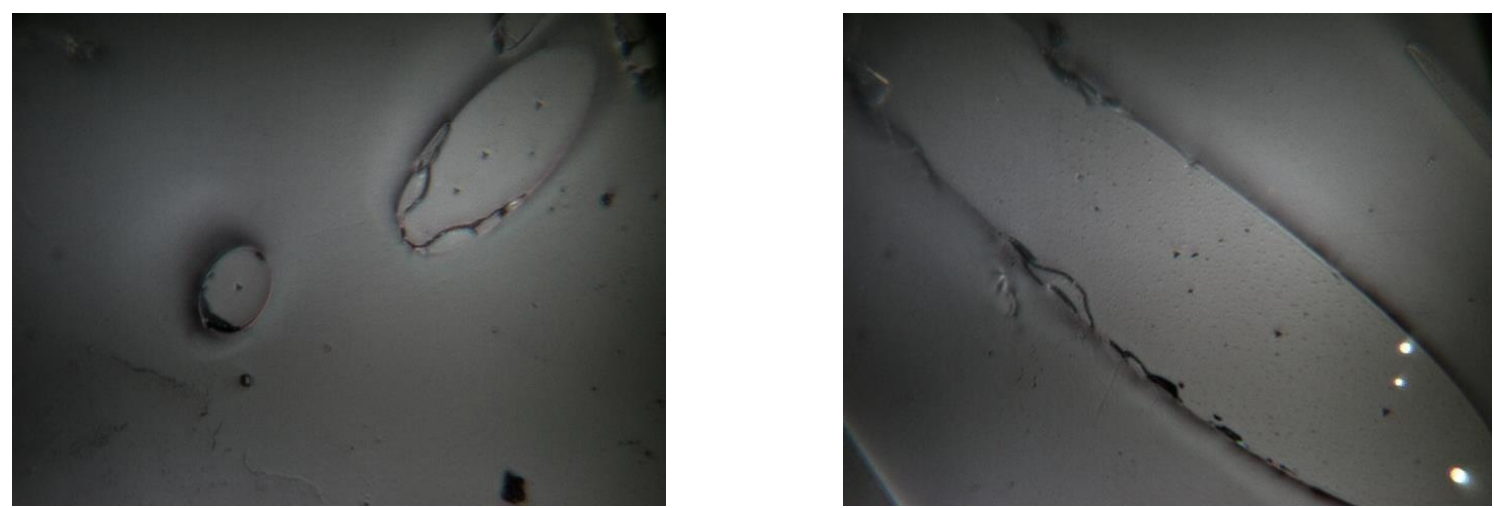

Figure 5:-Imprints on fibers based on a) B4D6 mixture and b) B6D4 (100x magnification).

Average measurements of Young's modulus and hardness on fiber sample based on all mixtures between the depth of $100 \mathrm{~nm}$ and $200 \mathrm{~nm}$ are given in table 3 . 
Table 3:-Mean values of modulus and hardness of fiber materials [4].

\begin{tabular}{|l|l|l|}
\hline Fiber samples & Young's module. GPa & Hardness. GPa \\
\hline B3D7 & 71.3 & 8.14 \\
\hline B4D6 & 67 & 7.49 \\
\hline B5D5 & 70.6 & 7.8 \\
\hline B6D4 & 72.6 & 8.2 \\
\hline
\end{tabular}

Average Young's modulus of fiber materials is about $70 \mathrm{GPa}$. Measured elastic properties for fibers B3D7, B5D5 and B6D4 are very similar .Sample B4D6 has the worse elastic properties (67 GPa). The obtained mechanical properties of fiber material samples are comparable with the mechanical properties of non-slag stone wool fiber, figure $6[3]$.

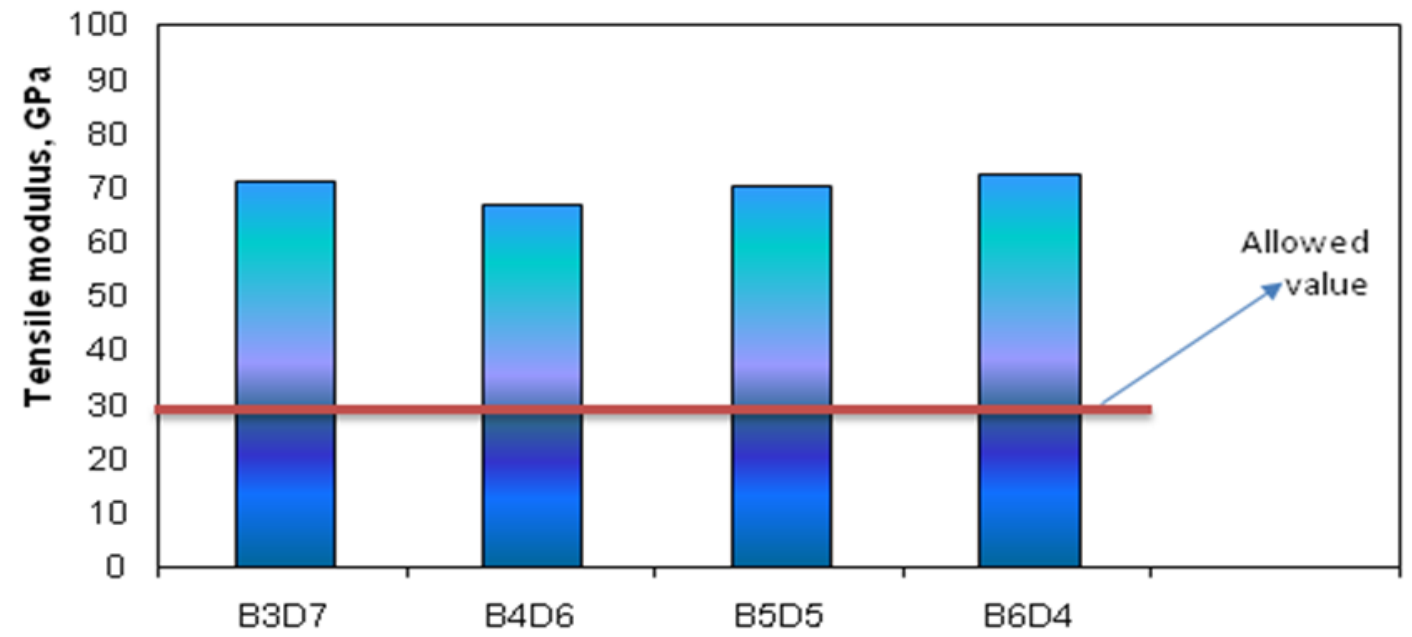

Fiber materials

Figure 6:-Comparison of mechanical properties of fiber samples[4].

Following the results of this research carried out on the formation of primary wool fibers based on mixture of blast furnace slag. it can be concluded that all prepared mixtures can be used for production of the stone wool fibers.

The use of blast furnace slag as the dominant component in the production of stone wool requires a comprehensive analysis from the aspect of quality and it has to be environmentally and economically justified.

\section{Conclusions:-}

1. Mineral wool fibers can be produced on the basis of prepared mixtures based on blast furnace slag.

2. The obtained mechanical properties of produced fiber are very similar with all samples.

3. All measured elastic properties for fibers are comparable with the fiber elastic properties of properties of nonslag stone wool fiber.

4. Research carried out on the formation of stone wool fibersbased on mixture of blast furnace slag and diabase shows that the blast furnace slag as dominant component can be used for production of stone wool.

\section{Acknowledgements:-}

The authors gratefully acknowledge the financial support by the Federation BiH Ministry of Science and Education. 


\section{References:-}

1. Mineral Wool I Putting Natural Resources to Work for the Benefit of our Planet (http://www.mineralewol.net/uploads/EURIMA-MineralWool_Sustainability_brochure.pdf)

2. Kraševec B. Bizjan B. Širok B. Glass wool layer formation in the collecting chamber. Glass Technol.. Eur. J. Glass Sci. Technol. A. 2017; 58 (1): 1-7.

3. Imamovic A. Bizjan B. Seferovic R.Mrvar P. Bombac D: MECHANICAL PROPERTIES OF MINERAL STONE WOOL FIBERS BASED ON MIXTURE OF BLAST FURNACE SLAG AND DIABASE. Int. J. Adv. Res. 7(4). 2019.DOI:10.21474/IJAR01/8967

4. Projekat: Osvajanje proizvodnje i karakterizacija kamene vune na bazi supstitucije prirodnih sirovina". Federalno ministarstvo obrazovanja i nauke. Univezitet Zenica. Zenica. BiH Projekat FMON 2017.

5. Chen J. Mrvar P. Širok B. Bizjan B. Melt film adhesion dynamics on spinning wheels. Glass Technol.. Eur. J. Glass Sci. Technol. A. 2019. 60 (1): 1-8.

6. Bizjan B. Peternelj M. Širok B. Mineral wool primary layer formation in collecting chamber. Journal of Mechanical Engineering 62. 2016; 3: 181-188.DOI:10.5545/sv-jme.2015.2995

7. Du PP. Lang Y. Li ZH. Zhang YZ. Effect of acidity coefficient of molten slag on properties of slag fiber Guocheng Gongcheng Xuebao/The Chinese Journal of Process Engineering. 2015; 15. 3:518-523. 